\title{
The Implication of the Scripture Genesis 11:1-9 in Multicultural Context of Indonesia
}

\author{
Merilyn \\ Institut Agama Kristen NegeriPalangka Raya \\ merilynyohannis78@gmail.com
}

\begin{abstract}
The biblical text contains many narratives that are relevant to human problems today. This paper is an exegetical study of the text of Genesis 11: 1-9 which contains a narrative about human arrogance and fear over their abilities and towards human differences. But God broke the arrogance and fear of humans by disrupting their communication. God's purpose is to show that diversity is a necessity. This research was conducted with an exegetical method by combining narrative and semiotic criticism approaches. This critical approach describes who the characters are and their role in the narrative, the narrative plot, the meaning obtained through words / symbols and time, as well as what narrative is discussed and the author's perspective. The purpose of this paper is to deconstruct and find the hidden meaning of the text as well as reconstruct it and discover the implications of the text in multicultural society in Indonesia today. And the conclusion reached is that the biblical narrative is always relevant to human life today. In the context of this paper, the narrative in the Tower of Babel story stresses that God values diversity and that diversity must be lived by everyone.
\end{abstract}

Keywords: Merilyn, Genesis 9:1-9, multiculturalism

\section{Introduction}

Indonesian society is a plural society that lives in an island nation, both large and small islands. The diversity of Indonesian society is very complex. The complexity of this diversity can be seen from ethnicity, class, culture, customs, language, religion. and in culture, customs and language it also contains diversity. Cultural differences are essentially due to differences in environmental adaptation and historical differences in cultural development. That had happened hundreds of years before Indonesia became a nation. After Indonesia's independence, diversity is still maintained. The founders of the nation really understood that. They maintain this diversity by allowing the nation and all its elements to live in the UUD 1945 and Pancasila. The complexity of Indonesian society in UUD 1945 and Pancasila known as multicultural society and multicultural nation. This paper is a combination of my interest in the study of the language of the Bible and social studies that aims to explore the meaning of the value of Pancasila for Indonesian people in a multicultural context. Genesis 11:1-9 is a part of Bible text which describe human history after the Story of Creation and the Flood.

The Christian tradition knows the story of the Tower of Babel as proof of the pride of mankind who wants to be like God. This tradition of church interpretation and teaching of the Tower of Babel is always connected with three things. First, church tradition explains that the Tower of Babel story is about human dissatisfaction. They do not accept their limitations and weaknesses as humans. Building a tower aims to break that supposition. The construction of the tower will show that they are powerful, strong, and solid. They want to be like God. Second, church tradition teaches that the Tower of Babel is the starting point for difference of 
the globe. Previously there was only one language and speech. And that language and speech are the power of the society. The same language and speech must be describes a united society. But God stopped them by confusing the one language. By confusing their language and speech, God creating many languages. The question is how does Allah mess it up and what is its purpose? God is a good God, isn't He? And confused language is negative connotations. The word "confuse" the word indicates a negative action. Is God is so evil towards humans? If $\mathrm{He}$ is not, why He doing that? Why there must be many languages. Does not one language and speech show unity and strength? Then why God wants many languages and speech among them? Third, church tradition teaches that the chaos is God's punishment, even God's curse. But the question is do humans sin because they have many languages? Of course not. They sin was arrogance which caused them ignored God's power.

These church traditions of the Tower of Babel story are not all considered to be wrong, but also not all can be justified. But it hundred years preached and taught from generation to generation in the church to the present so that Christians are trapped in poverty meaning the story. Christians understand that the story is about sinful humans and God punishment. Then this affects our understanding of God's relationship with humans and human relationships with others. These values of church teachings are those values that we also understand and live. Though many positive and still hidden values, which are unexpected can be extracted from the text. And of course gives enlightenment for people to interpret their lives in the world.

There are some goals of this paper. First, deconstruct and find find the hidden meanings of the text. Second, reconstract the texts by the narrative and semiotic critical approaches. Third, find the implication of the text in the today's multicultural of Indonesian society.

\section{Methodology of Research}

This paper doing by the biblical exegesis approach by combination of narrative and semiotic analysises. Exegesis is careful investigation of the original meaning of texts in their historical and literary contexts; the English word comes from a Greek verb meaning "to lead out of" (Greek "ex" = "out"; "agein" = "to lead/go/draw"); the process basically involves asking analytical questions about various aspects of the texts and their contexts [1].

I tried to explore the meaning of the text by combining narrative and semiotic analysis. The important parts that want to be highlighted in this paper are who is the character in the story, role do they play, the order of the plot,the patterns of meaning are conveyed deeper by words/symbols and what narrative time is discussed and the point of view of the writer and/or narrator.

\section{Result and Discussion}

\subsection{Text of Genesis 11:1-9}

The following below is the text of Genesis 11:1-9 basen on King James Version.

a) And the whole earth was of one language, and of one speech.

b) And it came to pass, as they journeyed from the east, that they found a plain in the land of Shinar; and they dwelt there. 
c) And they said one to another, Go to, let us make brick, and burn them thoroughly. And they had brick for stone, and slime had they for morter.

d) And they said, Go to, let us build us a city and a tower, whose top may reach unto heaven; and let us make us a name, lest we be scattered abroad upon the face of the whole earth.

e) And the Lord came down to see the city and the tower, which the children of men builded.

f) And the Lord said, Behold, the people is one, and they have all one language; and this they begin to do: and now nothing will be restrained from them, which they have imagined to do.

g) Go to, let us go down, and there confound their language, that they may not understand one another's speech.

h) So the Lord scattered them abroad from thence upon the face of all the earth: and they left off to build the city.

i) Therefore is the name of it called Babel; because the Lord did there confound the language of all the earth: and from thence did the Lord scatter them abroad upon the face of all the earth.

Let us see how text divided. Genesis 11: 1-2 is parallels to 11: $8-9$; both are narrative stories and emphasize the fact that once in a time the world only had one language in common. Genesis 11: 3-4 is parallels to 11: 6-7; both contain a direct sentence: "behold ..." and "let us ...". At 11: 1-4 shows human action and after at 11: 5-9 shows God's action. In chapter 11: 1 it says "one language and one accent"; the Hebrew text literally says they have one "tongue" (דָָָׁר - davar). This text means that all people at the time on that area speak and can understand accent (Isa. 19:18) and words (Ezek. 3: 5,6) each other. The area seen as a whole earth. Paul H. Selly asserted that there has been a universal agreement from the beginning to the present where every human on earth speaks the same language [2].

\subsection{Context of The Text Genesis 11:1-9}

The story of the Tower of Babel has a background in Mesopotamian socio-cultural and religious traditions. Immediately after the flood receded (Gen. 7: 21-24), it is said, only Noah's nuclear family remained on the earth. Since the sons of Noah, name Sem, Ham, and Yapet, humans began to grow and develop. The Semites were descendants of Sem, including Jews, who was the first inhabited the Mesopotamian region and later invaded Canaan. The Semites eventually developed countries such as Syria, Moab, Edom and Israel [3]. The descendants of Ham have relations with the people of Egypt, North Africa, and Canaan.Yapet's descendants living in the Asia Minor region. They were spread from there to the coast, possibly in Greece and Europe.

Although the descendants of Noah were spread, the tradition that recognizes that all humans on earth are one big family with the same language and culture continues to be believed from generations to generations [4]. Initially they were nomadic peoples who later settled in Sinear, in the Mesopotamian region. Sinear is a very profitable flat area for farming and animal husbandry. They chose Sinear and stay there more longer so that the culture developed well.

Later, in this place also the kingdom of Babylon or Babel will build (compare Daniel 1:2). Babylon was one of many cities built by Nimrod, son of Cush, grandson of Ham, son of Noah, 
in the land of Sinear. The city of Babylon is located on the banks of the Euphrates River, about 80 kilometers south of the current city of Baghdad (capital of Iraq).One manifestation of a very modern culture in Sinear at that time was the construction of a worship tower named ziggurat.Ziggurat is a symbol of the sacred mountain which is the resting place of the gods. So that it's shaped like a very high tower.

Similar buildings were also built in other several regions, such as in Ur which was built by King Nabonidus, who was enthroned from 555 to 539 BC. The kings in Mesopotamia had a much greater pride in building ziggurat than building city walls. There is also an Assyrian tower called the House of the Mount of the Universe and the tower in Borsipa is called the House of the Seven Guardians of Heaven and Earth.Besides the Larsa tower that called the Connecting House Between Heaven and Earth [5].

The existence of these ziggurats shows that the religious system and life of the Mesopotamian community is not only well preserved but also has an advanced religious civilization. As WismoadyWahono said, these ziggurats were expressions of the piety of the Mesopotamians [6]. It is logical if the material that use to build ziggurats is much higher quality than the material used to build city walls. The number of similar ziggurats in that many places at that time was thought to have inspired the construction of the Tower of Babel.

The story of the Tower of Babel comes from the Yahwist Source (Source Y), which portrays God as Universal. It was confirmed that the history of Israel was born in the context of world history. In addition, the election and salvation of Israel as God's people is not only about the interests of the nation of Israel but the universal interest. Like the contents of Genesis 2-3, the story of the Tower of Babel contains the story of aitiology, which is a story that reveals the reason why humans built towers reach the sky and many languages in the world and intends to explain the name of Babel [7]. (von Rad, 146).John Rogerson said that this story was debated because of the Bible which inspired by God for Jews and Christians and believed for centuries, was based on accurate science, history, and geography [8]. By stay at Sinear confirms the opinion and what is also written in the text is that they are not merely building towers but also building a city. It shows us that Sinear was being a more systematic and strategic place to live.

\subsection{Exploring The Text Genesis 11:1-9}

Before exploring why God came down and messed up their language. We should look at the reason why humans built the city with a tower. The Tower of Babel was a ziggurats which built as a temple. It was not a first tower, there were many towers has built before around their land and became common throughout Babylonia. The Tower of Babel may be a tallest and biggest tower. So that why it called a stairway to heaven.

Based on the text, the are two aims of building cities and tower. First, to look for names. Sentence "a city and a tower, whose top may reach unto heaven; and let us make us a name" (v. 4) seen clearly. It parallel with the meaning of want to be famous, arrogance, and ambition [9]. Second, lest humans be scattered throughout the earth (v. 4). Look at the sentence "lest we be scattered abroad upon the face of the whole earth." (v.4). In response to this, there are experts who argue that the Tower of Babel is a monument built for humans, which symbolizes human pride to reach the limits of heaven and force the Gods to submit to human will [10]. Similarly, Jacobs Isaacs asserted that the decision of humans to build city and tower which reaching the sky was aimed to equalize themselves with God, as powerfull as God. That power allows them to remain united as a nation [11]. In addition, the construction of the Tower of Babel preserved a particular culture after Flood era [12]. Human power make them able to 
conquer the whole world and keep it under their control. becoming many nations will threaten their unity. It is why Gerhard von Rad emphasized that the construction of towers could be motivated by insecurity and would be released from the bonds that had held them together so far. And the new nations would only breaking their unity [13].

Let us see on the third verse of the text. Human built the city and tower by the brick for stone, and slime had they for morter. Why did they used brick and slime not rocks and mud. Philip Smith said that bricks are made simply [14]. Bricks are more uniform in shape and size, but rocks are unique. Bricks and slime made by human's hand. The same material is certainly not unique. Likewise human. Look at the verse 6: "the people is one, and they have all one language". It clearly show that human is not unique and, of course, being weak.

But rocks and mud made by God. When build a building, each unique rocks is put together using mud to hold it firmly. The different shapes must be glued together in such a way. That makes it very strong and sturdy. God used uniqueness for making it stronger than brick. Brick is strong but cannot withstand the same stresses as rocks can [15]. So their purpose of built the Tower of Babel was not only about a building, but about their own satisfying. Unfortunatelly, God perceived their desire, and by His infinite wisdom, He knew this tower would only lead the them away from God [16].

Verse 5 it says "And the Lord came down to see the city and the tower, which the children of men builded," shows God's reaction. In Yahwist tradition the reaction of God is describing human action: "seeing" which in Hebrew uses the word רָאָ (ra'ah). The act "to see" of God is an act of His immanency. God does not see from a distance (read: heaven or from a position of glory) but God "came down" which means "coming closer". In addition, it meaned that God is existance and present by His reactions. That is confirmed in verse 7 that says, "Let us go down ...", in the Hebrew word (yered) means to come down or down. By "descending", God is depicted moving away from His throne then be at the site of the tower building on the earth. By "come down", God become close. God's present was not only to wacth what they do, but also to investigate the desires of the human heart. Look at the Jeremiah 17:10 God said "I the Lord search the heart, I try the reins, even to give every man according to his ways, and according to the fruit of his doings."

To understand God's reactions, there are three important phrases that we need to explore. Look at the sentence "this they begin to do..." (v.6). Contruction the city and the Tower of Babel will inevitably arise to other acts of sin. By knowing the intentions of the human heart, God sees that there will be many sins that will be done if not prevented. So this is God's preventative measure. Then, "confound their language" (v.7) and "scattered them abroad" (v.8) are the continuation of the prevous sentence. God prevent their will by confound their language and scattered them abroad.

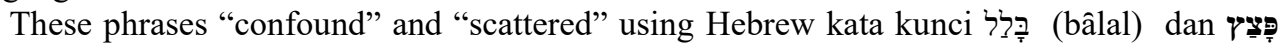
(patsats). Kata (bâlal) is a type of active verb qal means "to mix", "mingle", "confuse", which in the King James Version is "confound". God was a subject or doer who acts "to mix", "mingle", "confuse" the language of people in Sinear. Language is a symbol of identity and community entities [17]. Someone's uniquely identity known by language, culture, and characteristics. It is also means that language is not only about the unique accent or dialect, vocabulary, conversation and communication, but also the unique identity as an integrity. In relation to the construction of the city and the Tower of Babel, it is an effort to protect the only nation, culture and language that existed at that time.

God was not pleased. He made mixed and confused their one and only. According to William Elford Rogers, when God confused the language, He was not creating a new language, but rather mixing letters and syllables from the same original language [18]. 
Obviously it becomes a very confusing language. You can imagine the chaos that happened. On says commands but other mistook a mockery or one says thanks but other mistook a slander. The impact of chaos not only on their language, but ultimately also the city and tower building. They no longer have the same ideas and understandings. The differences destroys their integrity of their personality, and their culture adn nationality.

The phrase "scattered" is In KJV uses the same word "scattered". פָָ (patsats) is a type of verb niphal, which is a passive verb form of the verb qal, where humans as objects are "scattered" or "scattered". And why did God scatter them? God commanded Adam and Eve to "fruitful, and multiply, and replenish the earth, and subdue it: and have dominion over the fish of the sea, and over the fowl of the air, and over every living thing that moveth upon the earth." (Gen. 1:28). Can you see the difference between human desires and God's? When human wanted their unity, while God wants the spread. And how did they spread? The chaos has broke their communication and relation; no longer understand and know each other. They are alienated each other and no longer live together. They decided to separate (read: scattered). In my opinion, God did not drive them from the city and around the Tower of Babel, but it was their alienation. The scattering create diversity of new nations, cultures, and languages.

There are two purposes of what God has done. First, God merges their entities, and accompanied it by re-formation. God was not destroying them but transforming them into many nations. Second, God values the uniqueness of every creation and every person. These

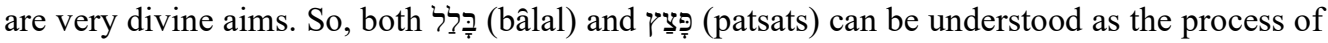
Allah's deconstruction as well as reconstructing nations into some new unique and different identities.

\subsection{The Meaning of The Text Genesis 9:1-9 For The Multicultural Context In Indonesia: An Implication}

Multiculturalism is an understanding and, at the same time, an attitude of acceptance of diversity, plurality and multiculturalism that exists in people's lives. Literally, the word contains recognition of the dignity of the people who live in their communities with their unique personality and cultures. Thus, each individual feels respected while responsible for living with his community.

Indonesia is a multicultural country; diverse in terms of ethnicity, culture, religion and social status, which inhabits hundreds of large and small islands. We encounter ourselves uniquely amidst all this diversity in ambiguity. On the one hand, we must understand and live the diversity. As the idealism of multicultural, our society is building dialogue between nations, cultures and religions. It is guiding our goals towards equality and justice. On the other hand, as the the Tower of Babel story, in this millennial era, some of us build and strengthen their existence within ethnic, cultural, religious, tribal, regional, gender, community-based backgrounds, educational backgrounds, skills, hobbies and etc. The reason is, they can support each other because of their identities, and also get a sense of comfort and security because of their identical and similarity. These communities are building the wall that limits them to the social world around them. For them, when outside the community they become insecure. Difference becomes a frightening threat. Horizontal conflicts that occur in this country are caused by differences not being able to be managed as property of the people and nation. It shows that the mindset of humans in the Tower of Babel era thousands of years ago is still alive today, in Indonesia. 
Nowaday, in Indonesia, multicultural harmony is still a challenge. Multiculturalism is still struggling to change people's perspective accepting differences openly. Indonesia has gone through many heartbreaking events that sacrificed a lot of property, lives and tears because of horizontal conflicts. Economic and social inequality is one of the triggers of conflict. The strong press the weak. Justice is more in favor of the authorities. Honestly, our struggle for a multiculturalist nation is still very long and winding. However, we must be optimistic that this condition is part of the process of forming the Indonesian nation into a multicultural nation.

Since Indonesia became a nation, in $17^{\text {th }}$ of August 1945, this country is based on the constitution both of Undang-undang Dasar 1945 and Pancasila. The visionary founders of the nation knew well the background of this very diverse country. They decided that Pancasila is the only right ideology to make this nation united. As an ideology, Pancasila uphold the values of justice and human right. Every regulation and law made, ideally, as reflection of Pancasila. Every person with ethnic, religious, social, economic, political background has the same right to obtain the rights to life; such as access to education, health, security, public facilities, economy, culture, suffrage and so on. The state protects each people because of the their right. And Pancasila will always protects their right. Pancasila, with the motto Bhinneka Tunggal Ika, respects each different uniqueness. All people who are protected and respected by the state are unique human beings. Indonesian history records that there were many people who wanted to destroy Pancasila. Until now it still stand firmly.

Pancasila and Bhinneka Tunggal Ika touched on the personal lives of each of its citizens in justice and equality as human rights. Every person, from ethnicity, culture, race, religion and social status, have a place to talk about and fight for human rights.Ideally diversity will surely meet at one node, namely human rights. Our country's history testimonied that the diversity results in prolonged conflict always leads to the neglect and disappearance of human rights.

Return to the text, God intervened in the construction of the Tower of Babel because $\mathrm{He}$ saw human rights violations going to happen.Dennis T. Olson, in The New Interpreter's Bible One-Volume Commentary, opens it for us; that the construction of the Tower of Babel has the tendency to abuse power, violence and suppression of human rights because human desires

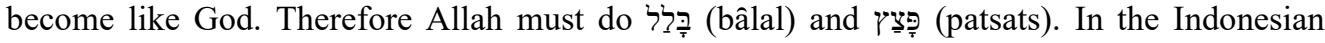
context, literally, the people of Indonesia have been scattered from Sabang to Merauke with very diverse backgrounds. Literally, also, רָָּ (bâlal) and Indonesian identity.Unfortunately, the values have not been applicated optimally in the spirit of the nation and state. In fact this spirit is in the values of Pancasila. The spirits לִ̣ (bâlal) and transform society and the nation. So that in turn help will our people understand themselves and responsibilities of the diversity. If all elements of this nation, in their diversity, have a good understanding of themselves and others, I believe, conflicts and intolerance that cause human rights violations will not occur.

\section{Conclusion}

The above description can be grouped as follows. First, the Bible is rich in narratives that talk about social, cultural and religious aspects. The context of Israel's life cannot be separated from all of these aspects. God's actions, in this case as an Subjects in many narratives, become central figures. Second, we are thankful that theology has many methods that can be used for Bible investigation. One of them is the exegese method. In this paper, narrative and semiotic 
criticism provides more possibilities for finding deeper meanings of interpretations that can be relevant to the present situation. This also confirms that theology will always be relevant to all developing science.Third, the narratives are still relevant to be discussed again in the present context. In this paper, the narrative about Menara Babel, with its critical exegesis method, has implications for the multicultural life of people in Indonesia today. The last but the least, the story of the Tower of Babel itself can be interpreted with many aspects and this paper captures one important aspect, namely God's openness to the diversity of humanity and it become a challenge for us to living it.

\section{References}

[1] Melugin, Roy F.: Canon andExegeticalMethod. pp. 46-60. Canon, Theology, and Old TestamentInterpretation, USA.FortressPress (1988)

[2] Paul H. Selly.:The Date of The Tower of Babel andSomeTheologicalImplications. pp. 20.WestminsterTheologicalJournal 63. (2001)

[3] Marshall, Celia Brewer.: A GuideThrough The Old Testament. pp. 32.Kentucky.Wesminster/John KnoxPress. (1989)

4] (Marsunu, 2008: 123).

[5] Youngblood, Ronald.: The Bookof Genesis: An IntroductoryCommentary. pp. 127. Oregon.WipfandStock Publisher. (1999)

[6] (WismoadyWahono, 2009:88).Wahono, S. Wismoady.: Di Sini Kutemukan. pp. 88. Jakarta. BPK Gunung Mulia (2011)

[7] Rad, Gerhardvon.: Genesis. pp. 146.Philadelphia. Westminster. (1961)

[8] Rogerson, John, andDavies, Philip.: The Old Testament World. pp. 196. New York.CambridgeUniversityPress. (1989)

[9] Olson, Dennis T.: The New Interpreter'sBible One-Volume Commentary. Nashville. AbingdonPress.(2009).

[10] Parrot, A.: The Tower of Babel. pp. 68. New York. PhilosophicalLibrary.(1955)

[11] Isaacs, Jacobs.: Our People: HistoryoftheJews : A TextBookofJewishHistoryfortheSchoolandHome: Book 3 \& 4. MerkosLinyoneiChinuch(1998)

[12] Alston, Wallace M. andWelker, Michael.: Reformed Theology: IdentityandEcumenicity II: BiblicalInterpretation In The ReformTradition.Vol 2. pp. 139. Michigan. GrandRapids.(2007)

[13] Rad, Gerhardvon.: Genesis. pp. 147.Philadelphia. Westminster. (1961)

[14] Smith, Philip.: A smallerAncienthistoryoftheEast. pp. 110-111. London. John MurrayAlbemarle Street.(1871)

[15] (https://standingbehindgod.wordpress.com/2014/07/13/tower-of-babel-brick-or-stone/).

[16] (https://www.learnreligions.com/the-tower-of-babel-70021).।

[17] Abdullah, Irwan.: Bahasa Nusantara. pp. 111. Jakarta. Pustaka Pelajar.(1999)

[18] Rogers, William Elford.:Interpretation in PiersPlowman. pp. 36. Washington DC. The CatholicUniversityof America Press.(2002) 